\title{
A Research on Employment and Unemployment: Case in Turkey
}

\author{
Mehmet Saim AŞÇI iD a Sabri ÖZ iD b \\ a İstanbul Medipole University, İstanbul, Turkey. msasci@medipol.edu.tr \\ b Istanbul Ticaret University, İstanbul, Turkey. soz@ticaret.edu.tr
}

\begin{tabular}{|c|c|}
\hline ARTICLE INFO & ABSTRACT \\
\hline \multirow{5}{*}{$\begin{array}{l}\text { Keywords: } \\
\text { Employment Policy } \\
\text { Unemployment } \\
\text { Active Employment Policy } \\
\text { Dynamics of Employment }\end{array}$} & Purpose - It is to evaluate active employment policies by examining the types of unemployment in \\
\hline & Turkey. \\
\hline & \multirow{6}{*}{$\begin{array}{l}\text { Design/methodology/approach - The methodology of this article is literature review. For Turkey's } \\
\text { employmen policy, the type of unemploiyment, Dynamics of unemploymen and the characteristics } \\
\text { of unemployment subjects are investigated. After a brief introduction, the coming first part of the } \\
\text { article consists of general concepts of employment and unemployment. In the second part majör } \\
\text { unemployment types have been investigated. Next part is about the employment policy and the } \\
\text { dynamic factors of employment. At the end of the article it has been discussed whether active and } \\
\text { passive employment policies are enough or not for Turkey. }\end{array}$} \\
\hline & \\
\hline & \\
\hline Received 10 October 2019 & \\
\hline Revised 20 December 2019 & \\
\hline Accepted 26 December 2019 & \\
\hline \multirow{4}{*}{$\begin{array}{l}\text { Article Classification: } \\
\text { Research Article }\end{array}$} & Findings - The articles main outcomes are the basic conceptual information about employment \\
\hline & and unemployment where as the main findings are the edequacy of the current applied policy \\
\hline & $\begin{array}{l}\text { especially on active employment policy in Turkey. It is important that under technological } \\
\text { development the traditional policies should be transformed. }\end{array}$ \\
\hline & $\begin{array}{l}\text { Discussion - The main discussion subject is the policies which are used for decreasing } \\
\text { unemployment are enough or not as education and technology Fundamentals are in } \\
\text { transformation. }\end{array}$ \\
\hline
\end{tabular}

\section{INTRODUCTION}

Unemployment has many impacts on the individual, but it also has negative social consequences. This concern will be primarily applicable to an existing unemployed person, as well as the concern of unemployed people for a job in employment, instead of peace and security in the work life, brings together anxiety and future anxiety. Naturally, it has also effects as such a personal psychology, low yield, tense worker-employer relationships, attention to work and decrease in relevance (Ekin, 1971, p. 3).

There are two major misfortunes arising from unemployment: the first creates a sense of being useless, undesirable people in the unemployed; secondly, unemployment brings fear to people's lives, and this creates fear of fear (Beveridge, 2014, p. 248)." When it is generally called unemployed, the first thing that comes to mind is lack of professional skills and lack of ability. While this understanding accepts existence more prominently before the diffusion of technology, there are some professions that disappear with technology and perceptual differences with new working concepts. This kind of thought, which was introduced in the period when the industrial revolution was accelerating, is partially valid in developing countries. It is understood that the industrial and industrial age in which we live is in the economic structure of societies. For the unemployed large masses, individuals may be unemployed, willing to work, and in their power.

Unemployment is a social case and a social phenomenon. This phenomenon requires a solution for governments. Employment policies such as full employment policy, active and passive employment policies are important to ensure economic development. With the full employment policy, countries were able to give the

\section{Önerilen Atıf/Suggested Citation}




\section{S. Aşçı - S. Öz 11/4 (2019) 3221-3244}

existing human power to the economic development order. The difference between the level of employment and the level of employment, which is in the power and desire of the working population of a country, and which represents the work part of the labor force and the working part of this workforce, is expressed as unemployment (Zaim, 1977, p. 133).

With the developing of technology, there are some changes in every way of humen life and society. It is obvious. And hence, there are some major reflections to the working life style. It has been started in the Europa so called active employment policies, beyond passive policies it is applied in many countries. In general, social benifits programme, the subsidies in wages and employment, on-the-job training and entrepreneurship educations are importatnt issues on active employment policies.

This study is important for both Turkish and the world's economy, where unemployment and labor issues on the agenda of the intensive is important because of the currently doing a survey and definitions. It is also important that the study focuses on the types and social benefits of active employment policies by addressing employment policies.

In the study, the first two parts below focus on the definitions and concepts, whereas employment policies have been investigated, in the last part as an implementation in Turkey and finally will have a discussion.

\section{UNEMPLOYMENT AND EMPLOYMENT CONCEPTS}

\subsection{Unemployment Types and Concepts}

Unemployment is a phenomenon that is felt by the development of industry. Unemployment is the main source of the so-called Ludizm, which is expressed as a machine breaker in the early years of industry. Unemployment is the main economic problem of the modern industry. In this way, unemployment is perceived in different ways within the current terms, but it is manifested in a different way in the literature. As indicated in the dictionary unemployed person individually "no power, idle, naughty". On the other hand, the job in TDK is expressed as a value creating labor, the word unemployed is expressed as the person without job. In this case, it can be expressed as the person who is deprived of creating an unemployed value from the two definitions.

In the literature, unemployment is expressed in different ways. It is stated that unemployment has certain conditions and conditions, and it can be expressed as the following: Whoever is in power and power, is called unemployed who is not able to find a current and a valid wage, but also a law, or a person looking for a job within the appointed time (Ülgener, 1976, p. 108-109). On the other hand, according to this definition, these three statemenst coudl be declared. The first one, is as: "The first condition is to be at work and power. In order to be included in the labor force, it must be the person who fulfills this requirement. It is not considered as unemployed not to desire to work while it is open, the employee is in need, the job and the field is suitable." Secondly, the current wage and prize limits should be understood as: "Depending on the type of work being sought, the relative importance of the economy in the country, there is a conventional wage or a customary wage. It is not necessary to consider anyone who is looking for a job and who is not exposed to it because of the claim that it does not agree with this roll and cannot handle the job site it wants to work". And the third statement, "It is of the same importance to indicate unemployment in hours defined by law or custom. A person is not considered to be unemployed if they cannot find a job or not at the time of these hours."

Finally, unemployment means that the person concerned is not a state of ineligibility which has arisen from the voluntary counter-resistance of the person concerned, in other words, in a voluntary way.

\subsection{Modern Industry and Unemployment}

According to liberal arguments based on the views of the Physiocrats in the 18th and 19th centuries, unless a state intervenes in the industry in a society, it is impossible for a healthy and powerful worker to be unemployed except for his own flaws and desires.

Unemployment does not arise from a personal defect, (out of exceptions) unemployment is the problem of modern industry. It arises from the structure of the economic system based on the factory industry. 


\section{S. Aşçı - S. Öz 11/4 (2019) 3221-3244}

After the development of the leading unemployment factory industry in the division of labor and since the 19th century has gained importance. Because the absence of standard manufacturing in the previous periods of the factory industry, the fact that the workers were mainly engaged in small industry and agricultural work, were talking about a wider elasticity in terms of changing the type and order of production during the work-outs.

Almost during the whole 20th century, the highly developed division of labor made it very difficult for the workers, who worked and specialized in their own arm, to transfer their jobs to other parts that demanded specialization, even without knowing the general result of the manufacturing situation.

In the millennium period, it is possible to see a different face of modernization. Unemployment is discussed with the factors such as Industry 4.0. A large number of jobs will be removed in a short time. The new occupations will be based on human capital. In the short and medium term, it is stated that the unemployment problem will become more complicated, but there are important sources in the long term that a balance will occur again.

\subsection{Unemployment and Full Employment}

In order to eliminate unemployment, various measures have been applied in all countries especially after the crisis of 1929-30. Especially the annual wage guarantee, the planning of technological innovations, the transfer of the governments of the budget policy, the transition of the state to the new job fields, the activities such as some measures can be expressed. The aim is to provide jobs to every citizen who has the desire and power to work in society. However, even in the most prosperous periods, one hundred percent full employment has not been achieved.

In the last quarter of the 20th century, Turkey has emerged differences in their employment policies. In addition to the passive employment policies, active employment policies have also started to be implemented. ISKUR, known as the Employment Agency, has been the implementing agency of active policies (Ay, 2012, p. 336).

Unemployment insurance and early retirement are known as passive employment policies. On the other hand,

a) Public matching and consultancy services

b) Vocational training

c) Subsidized employment (private sector subsidies, own employment in the public sector v.s.)

d) Policies towards youth

e) Disability policies

is known as active employment policies (Biçerli, 2004, p. 45).

Full-employment is the level of employment for all who want to work at the current wage level. In fact, such a situation occurs in the form of more vacant job seekers. In other words, the fact that some people are unemployed is not irreconcilable with full employment. As long as there is enough space to employ these unemployed. Indeed, it is difficult to envision a day or a moment when everyone who wants to work is working and no one is unemployed. There are a lot of people in a country who are new to their jobs and looking for another job any time. It is necessary to differentiate this state called frictional unemployment, from real unemployment (Aren, 2008, p. 21).

In an underdeveloped economy, (also in developing country) underemployment presents itself in the form of laziness and inertia rather than explicitly and intolerably unemployment.

For this reason, many countries have adopted the definition of a high and stable level of employment instead of full employment. In this case, $2 \%$ and $3 \%$ of unemployment is possible with full employment provided that it corresponds to frictional or seasonal unemployment (Zaim, 1977, p. 139). 


\subsection{Characteristics of Unemployment in Developing Countries}

In the theory of economics; Employment and its inverse unemployment are worthy of consideration in mature and wealthy countries, which have reached advanced industrial levels. When the mass of goods and investments in this country from time to time can not be melted in the abundance of goods at the expected prices, stocks are stacked on top of each other, underemployment and unemployment become inevitable.

In agricul-turalized and conventional agricaltural techniques used countries, the economic crisis increases the number of those who participate in the production of the family environment in order to compensate for the low income and to remain hungry at least where there is an open unemployment. So on the contrary it expands employment.

The parties to which such a thought is right are of course not. In an underdeveloped economy, underemployment introduces itself to the naked eye as a form of laziness and inertia rather than an explicit and informal unemployment.

The view of the village, town and city coffees is not much different than before. However, it is possible to shed light on not all of the truth but to one corner. It is impossible not to notice that the colors will change when looking at other corners. It is not today our foreigner, as it was yesterday, when the town was literally out of the country and its labor was unfortunate and the word was literally an unemployed crowd.

Let us immediately say that this kind of unemployment is different from the advanced industry hometown; but the destructive effect and the results are never less grave. The difference is: Against the period of continuous development in the industrial countries since the nineteenth century, against the periodic unemployment caused by friction and blockages, there has been a period of uneasy unemployment and underemployment, which has been around for a long time in agricultural countries. In the first one, the total demand is unpredictable, and the second is the increase in population growth and the rate of increase.

The whole difference is that the problem, which is transient on one side, is that it continues on the other side as it is digested into the conditions of the body. Unemployment in today's underdeveloped (and developing) countries shows a more complex and intricate landscape than in western countries. While these countries are industrialized with the effort given by the potential power stored in their country's recipes, the encounters with the types of unemployment that are more advanced to the economically advanced countries are the continuation of the state which is temporary on the other. Unemployment in today's underdeveloped countries shows a more complex and intricate landscape than the western countries. While these countries are industrialized with the effort given by the potential power hidden in their signals, they are destined to encounter the economic types that are unique to the advanced countries. On the other hand, incomplete employment (hidden unemployment) mixed with the inertia of being underdeveloped continues as before. For this reason, ignorance or underestimation has a serious importance on its place.

\section{MAJOR UNEMPLOYMENT TYPES}

It is stated that, in many articles, there are mainly three types of unemployment: Stuctural, frictional and cyclical where as structural and frictional unemployment make up the natural unemploymen and the cyclical one occurs by the insufficient demand, usually during a recession (The Balance, 2019). In this article the first three main unemployment and would be explained briefly. And the rest of the unemployment types as: Voluntary, Informal, Seasonal, Technologic, Continues and Confidential Unemployments are simply exlained. Some other literature lists and includes also Natural, Long Term, Underemployment, Real Unemployment etc. Natural Unemployment is explained as there will be always as natural a bit and acceptable rate of unemployment, even in balance and developed countries' well functioning ecenomy.

Unemployment classiciation as youth, rural, urban, aggrigarian and non-aggrigarian sectorel and gender classifications are also stated by the statistical officially with in the TUIK (Turkish Statistical Foundation) data. 


\section{S. Aşçı - S. Öz 11/4 (2019) 3221-3244}

However, TUIK has been founded and well functioning with its name of TUIK after 2005. Before that, enflation, unemployment and such other macro statistics are indexed and measured by other institudes and foundations. For Turkey, it is important that, the integration standards have been made after Millenium. So there would be a problem to obtainin healty data before Millenium. The measuring system has been changed after 2005 (Öz, 2017, p. 45).

\subsection{Naturel Unemployment}

A theoretical tool used to measure the effectiveness of the labor market. It is not possible to provide $100 \%$ employment in a labor market due to temporary, structural and cyclical factors. A small part of the workforce is always unemployed. This is called the natural or normal state of the effective labor market. The natural unemployment rate is considered to be $5 \%$ of the total labor force.

The phenomenon of natural unemployment has no universal meaning. It differs from situation to situation. Each labor market has its own Natural Unemployment Rate which shows its own dynamics and characteristics. Natural Unemployment in active labor markets with adequate investment levels and in which there are plenty of open jobs, total demand is low and lower than those in which labor market information system is inadequate. Natural unemployment is also high in cases where existing technology replaces the workforce.

The importance of the concept of natural unemployment stems from its effects on Employment Policy. If the major part of open unemployment comes from natural unemployment, more radical reforms or more specific labor market interventions are needed instead of macroeconomic policies prepared to prevent unemployment (Özay \& Kılıç, 2009, s. 19).

\subsection{Structural Unemployment}

Unemployment caused by the changes in the economic structure of a country is called structural unemploymentFor example, in a country where agricultural production is carried out by means of primitive methods, if the machinery is started to be produced by machinery, the amount of workers who lose their opportunities to work in the village will increase as machine production becomes widespread. As long as such structure changes continue, this kind of unemployment will continue in the economy.

Some authors consider structural unemployment under the concept of technological unemployment. Some of them also call for structural unemployment in the developing countries and to the continuous unemployment. In this respect, it is more appropriate to look at the meaning of terms. In this sense, unemployment is a kind of unemployment which is caused by various economic factors. Changes in the economic, social and cultural life of societies, changes in fashion and fashion changes give rise to the lack of unemployment.

For example, the development of artificial silk and synthetic fibers instead of naturel silk, the use of motor vehicles instead of prohibiting the use of carts and carriages in a country where the carriage is used causes an unemployment resulting as the structural changes in that society.

For example, in the Ottoman Empire during the period of the Second Mahmut, as a result of the adoption of the European setas and trousers and fez, the importation of pants and trousers resulted in a great unemployment in the field of clothing and dredge production.

\subsection{Frictional Unemployment}

The relatively harmless form of unemployment in every economy of a normal economy is the frictional unemployment that is incurred during the place and occupation.

Undoubtedly, how much incidental and frictional unemployment can occur in a country, depending on whether the labor markets in the country are well organized.

This type of unemployment, which can be found in every country whether or not developed from economics, arises from the inability of the labor market to function well. The reason of such unemployment is neither the inadequacy of the demand, the change of structure, nor the constraint of the means of production. This type of 


\section{S. Aşçı - S. Öz 11/4 (2019) 3221-3244}

unemployment can only be attributed to a variety of factors, from temporary reasons such as the availability of workers who do not know where to find work or where the displacement is costly and cumbersome. For example, in a country some people may be unemployed while some employers may be looking for workers. In this case, the reason for unemployment is not the lack of demand, but only because the workers are unaware of the current employment opportunities or they cannot bear the expense of going to their places of employment (Üstünel, 1990, p.111).

There is no doubt that the frictional unemployment in a country will depend especially on whether the labor markets in the country are well organized.

Since every individual in the economy is free to keep his / her job and relocate, it is possible for some labor to remain unemployed for a few weeks and sometimes even under the most favorable conditions. A part of the workforce in a community filled with law and occupation staff may be subject to temporary unemployment due to a change of place and assignment in one way or another. This unemployment is expressed as the more insoluble residue of unemployment (Üstünel, 1990, p. 174).

Even in countries where the labor market is the best organized, the number of such unemployed people is around 2-3\% of the working population and not lower (Üstünel, 1990, p. 113).

\subsection{Cyclical (Conjunktional) Unemployment}

This type of irregular unemployment, called cyclical or cyclical unemployment, arises from the fact that economic life has not always been able to maintain the same level of activity and has fluctuating fluctuations.

In the depression phases of these conjuncture fluctuations, in other words, in the economies where economic activity decreases, large labor masses may become unemployed in a national economy; and such unemployment may continue for a long time. If economic activity is expanding and the conjuncture begins to rise, this unemployment can be diminished and disappear completely; However, after a while, the depression phase will be shifted again (Üstünel, 1990, p. 171).

The reason for cyclical unemployment is lack of demand. This type of unemployment is rather important for economically advanced countries. The cyclical expansion and contraction of the volume of economic activity is a very old phenomenon and the most intense and frightening is the one that started in 1929.

After the big depression, 1929 crisis, the unemployment rate was $25 \%$ of the working population in the USA and started to decrease towards the second world war due to the population of the war-caused labor force. It is unfortunately not possible to say that the causes of the conjuncture movements are now a unemployment, a memory of the past and will not recur. Indeed, after the war, U.S.A. 1949, 1954 In 1958, 1961 and 1971, 1929, despite the fact that it is not comparable to the intensity of the crisis, the contraction in the economic activity. These observations show that in economically advanced countries, there is a full operational incidence for a year, and that the volume of economic activity is mostly below full employment (Zaim, 1977, p. 153-154).

\subsection{Voluntary Unemployment}

As it is understood from the previous explanations, voluntary unemployment is a concept among those who have the power to work as voluntarily unemployed because they refuse to work if they are willing to work if they agree to the current level of wages and working conditions.

Reasons for voluntary unemployment may be found by investigating why people sometimes choose not to work. Some people just prefer to be unemployed because they are lazy and idle disposition have they wander from the slightest pretext for a reason.

For example, in voluntary unemployment; They leave the job in the face of a slight change in business conditions and prefer not to work under these conditions. Another reason, perhaps the most important reason for unemployment is the fact that the income demand of some individuals or families has very low elasticity. Although a family has more than one member who can work, sometimes it is seen that only one person works in 


\section{S. Aşçı - S. Öz 11/4 (2019) 3221-3244}

the family, the others are not working. If this family does not have a strong desire to reach higher levels of income, that is, if the demand for income is inelastic, there is no economic motive that will lead them to work more.

Therefore, the fact that the demand for income is not severe can reduce the amount of money that will be offered in return for income under certain conditions, which may lead to the emergence of voluntary unemployment.

Meanwhile, it is important that, if there exist voluntary unemployment somehow it should be stated logically involuntary unemployment. The unemployment out of the voluntary unemployment is called involuntary unemployment. For instance, with the developing technology, the lay-off's are involuntary unemployed with in the referns time, even they seek a new job and ready to work. The involuntary unemployment, at the end, may causes to refuse new challenge and may cause to social inertia (Seyyar, 2011, s. 144).

\subsection{Informal Unemployment}

Informal Unemployment is the type of unemployment, which is frequently seen in the societies where the division of labor and specialization is advanced and which is of fundamental importance in economic terms. Unlike in this kind of unemplo, p. yment, voluntary unemployment, those who are unemployed are not willingly unemployed, and they are not dependent on their own efforts. Sometimes conditions in an economy can be so that under these circumstances, some workers are unable to find a job even if they agree with the current wage rate and business conditions. Those who cannot find a job even though they have a desire to work are called irregularly unemployed. One of the most important reasons of this kind of unemployment is lack of demand. In a national economy, sometimes it is not possible to sell all of the goods and services that the production factors can produce, the effective demand may be at a low level which does not allow to use the whole of the existing production capacity. Therefore, some workers are willing to work at the current wage level, but for a long time, they may become incapacitated. This type of unemployment is called irregular, actually informal, unemployment because the low level of demand is due to some reasons beyond the will of the unemployed population and they do not have the opportunity to change them (Üstünel, 1990, p. 168).

In many literature, informal economy yields with and used the term for labour market informal employment rather than informal unemployment.

\subsection{Seasonal Unemployment}

The reason for unemployment may be the seasonal fluctuations of economic activity. In some professions and in some fields of activity, the possibility of working according to seasons varies according to seasons. As regards the season, work opportunities in the field increase, and in the case of seasons unemployment begins (Üstünel, 1990, p. 170).

There are two main reasons for seasonal unemployment. The first is the direct and immediate effect of seasonal unemployment. the second is the reasons that affect the more general and seasonal unemployment.

The reasons for the first type are the weather conditions and the seasonal changes. The second kind of reasons are the factors arising from the industry itself and related to the development of the business division. Weather conditions and seasonal changes often cause seasonal unemployment by affecting the supply of production. For example, in agriculture, construction, brick, lime, stone, soil and sand products industry, such as the production of natural conditions in terms of natural conditions are not maintained for a whole year, causes production to stop in certain seasons. On the other hand, in some other industrial branches, unemployment may be seen due to the change in demand in certain seasons. This is seen only in the manufacture of swimsuits, fur, coal and stoves, which are produced in a particular season. Production in this type of industry can be sustained throughout the year, not a change in product supply, but changes in demand against the product cause seasonal unemployment. In the country where the country has gone forward, the seasonal unemployment is mostly due to the changes in the demand of the goods and this situation is related to the structure of the production. 


\section{S. Aşç1 - S. Öz 11/4 (2019) 3221-3244}

In the non-industrialized countries, seasonal unemployment is generally related to the supply of the product and not from the demand of the first group but from the seasonal changes in production. Because this situation is related to the structure of agricultural production.

Important issues of employment in agriculture in countries such as Turkey, unused for a long time work force in the current year but not separated from agriculture ie technological levels which is seasonal unemployment. The highest rate of unemployment in Turkey season from December to February, the lowest rate coincides with the July-August.

\subsection{Technologic Unemployment}

This type of unemployment is the result of machine substitution instead of manpower or the application of more productive methods, and it is the result of machinery. Recently, this issue has become the subject of the day in developed economies.

Mostly conservative writers declare that technological development will eliminate the unemployment in the short term by opening up new jobs in the long term. But in the short term and on an individual basis, the situation changes. Because the use of more advanced machines with technological means or the increase in the number of machines per worker increases the efficiency on the one hand, while providing useful results for the individual business and society, on the other hand, the machine is replaced by workers who are not replaced.

However, it should be pointed out that it is not possible to claim that any technological development, which enables the increase of physical productivity (productivity) to the head, will definitely lead to unemployment. If the demand for consumption and investment goods in the country, which adopts a technical innovation that will save labor, is increased at the same rate as the increase of physical product per capita, there is no need to worry about technological unemployment. Because the labor force that will be left open by technological progress, consumption and investment goods industries, which can expand with the courage they receive from the increase in demand, will be able to meet the workforce demand and the elasticity of employment.

On the other hand, in any field, if the productivity increase proceeds at higher rates than the total demand and the lack of demand in other areas, technological unemployment will be inevitable (Lewis, 2013, p. 141).

These workers' finding a new job or adapting to a new job is particularly difficult when technological unemployment is widespread. Therefore, it is both socially and economically necessary to take measures for the protection of technological unemployed. It is socially necessary, because; it causes injustice in sharing the burden of development and causes social or political turmoil in society. It is necessary for economic reasons, because if workers are not protected against technological unemployment, trade unions take the stage of technological development and no one increases the efficiency. This situation is important for developing economies as well as for developed economies (Zaim, 1977, p. 148).

Especially, with the beginning of millenium, post digital transformation in the information society, would be in negative relations in the short and mediium term with unemployment. In the Humans of machine Age, Management Strategies for Redundancy, article, Civelek pointed out that there would be a transformation on technology, as shown in the figüre 1 below, would have a relationsship on labor market in the future. Labor market is shown within the same ecosystem with the technological transformation (Civelek, 2018, p. 91).

The figure 2 illustrates the change in workforce structure by the change of technology, by the McKinsey Institute analysis.

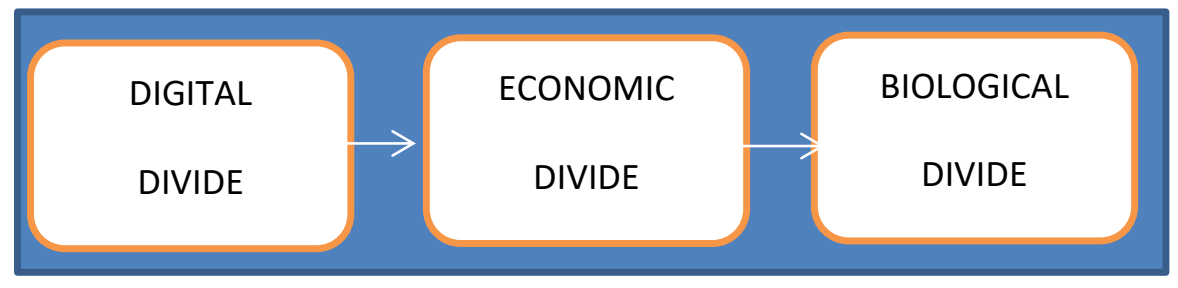


M. S. Aşçı - S. Öz 11/4 (2019) 3221-3244

Figure 1: The Dynamics of the post digital ecosystem.

Source: (online) http://www.emrecivelek.com/wp-content/uploads/2019/01/Humans-of-Machine-Age.pdf

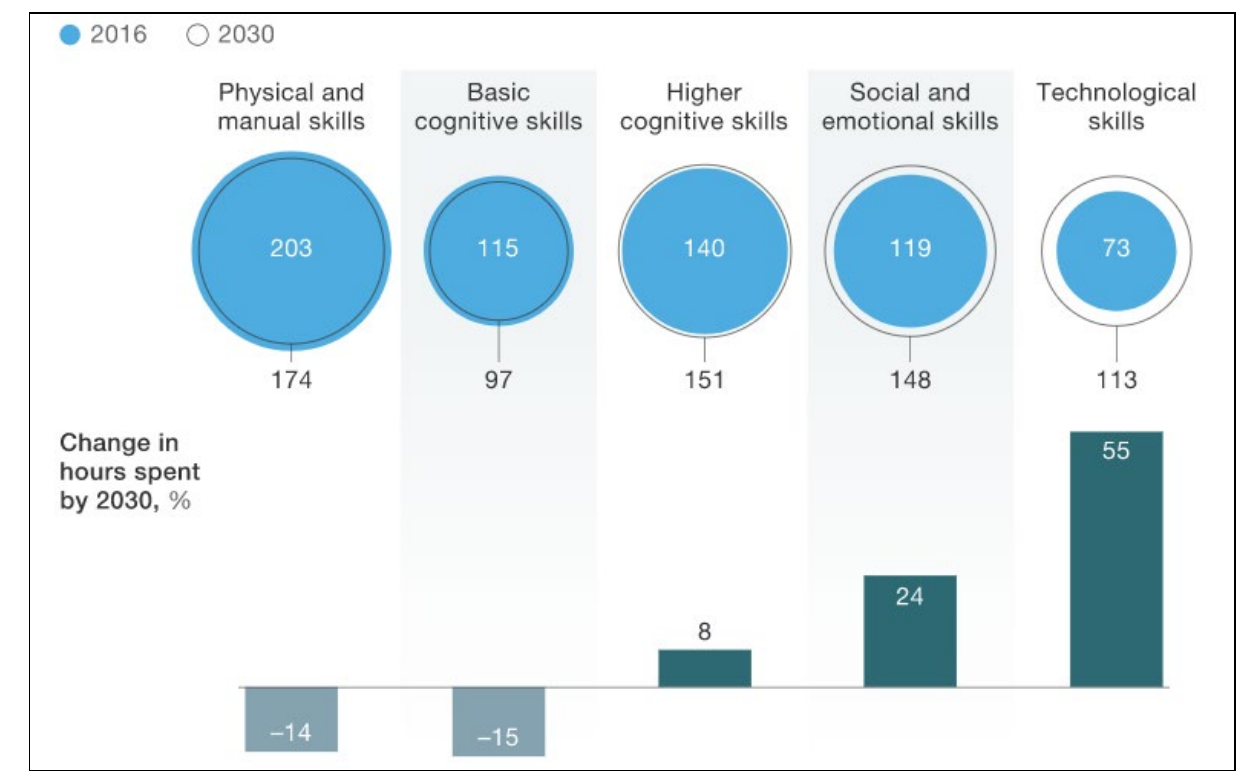

Figure 2: Total Hours worked in Europa and United States, 2016 vs 2030 estimated values, billion

Source: (online) https://www.mckinsey.com/featured-insights/future-of-work/skill-shift-automation-and-thefuture-of-the-workforce, last Dec, 17th, 2019.

\subsection{Continuous Recession}

Rather, the regression and stagnation of an advanced and mature economy may leave more people unemployed and inefficient. As a matter of fact, most of the advanced economies of the past have completed their lives in such a stagnation. According to its place, rival countries are cheaper, more abundant, and the profitable production or trade routes have changed the efficiency of customary methods from centuries ago, and the economy has been doomed to continuous unemployment. The fact that the exposed masses migrate to the big cities and increase the urbanization and cause the social restlessness, and the fact that the out-of-city employment and inefficient manpower inevitably lead to the formation of harmful livelihoods, has made the economic regression harder and harder (Ülgener, 1976, p. 113).

Although it has been seen that these conditions arising from the structural features of developed and developing countries except for the various types of unemployment that we have seen so far have been strengthened, after the crisis of 1929, centuries-old or continuous stagnation has emerged among the economists. The reason for this is that the idea of all these types of unemployment have developed in the economic structure, which is based on the private enterprise principle called capitalist economics system, and that the disease will become increasingly progressive.

However, with the opening of new business areas fueled by the second world war, the western economies have reached a welfare period, while maximum effort has been made for the implementation of the full employment policy and technological developments are not decreasing, and the continuous stagnation has lost its importance. Developed countries, which are rich in economic resources, have been a provocative factor in emerging economies. For this reason, it is believed that the economic developments of societies can be continuous (Zaim, 1977, p. 154).

\subsection{Confidential (Hidden) Unemployment}

All of the various unemployment we have examined above are in a sense open unemployment. Because, in structural, seasonal, cyclical unemployment, it is clear who is unemployed. In the case of hidden 


\section{S. Aşçı - S. Öz 11/4 (2019) 3221-3244}

unemployment, the situation is different. Because, in this kind of unemployment, what may be considered unemployed may be working, or they may seem to work. But they cannot contribute to total production. Their contribution to production is either zero or very close to zero.

Confidential unemployment is defined as follows: provided that production technology remains constant, there is hidden unemployment in the area of activity if some of the people working in any production branch would not work, there would be no reduction in the aggrigate production volume. The reason for hidden unemployment is not only the lack of demand, but rather the lack of demand, but rather the lack of physical means of working, in other words, capital equipment. In other words, the unemployed in these countries are still doomed to be unemployed, even though there is no machinery and equipment required for their work, even if they feel the need to work (Üstünel, 1990, p. 172).

In the face of the shortage of productive workplaces, the large mass of labor force has accumulated to the areas of livelihood limited to livelihoods so that the contribution of each to total production is reduced to an amount that is almost non-existent or even to zero. Most of the individuals either work with the help of the city and pitifully, take shelter in the fields with a fee close to the throat toughness. In the crowded districts of the city, peddlers and ferries, caravan, soap, lottery tickets, such as the vending trader, shabby and tacky people are in the same situation (Aren, 2008, p. 17-18).

In this respect, it is not wrong to establish a close relationship between vendor cries and secret unemployment in a city. The fact that he sees hidden unemployment in all these forms is that a person will see the work done very often for half a dozen and maybe more people. Unemployment is not just about numbers. In order to complete the list, it would be appropriate to add to the above figures the unemployment arising from the drowning and bottleneck of economic development. Some of the most likely memories are:

a) Blockage caused by lack of equipment and inventory and as a result,

b) Blockages caused by imports; In this case, due to the contraction of dental payment facilities,

c) An unexpected contraction in financing resources, especially credit supply, and workplaces caused by hardening, breaks and unemployment

The above explanations can also give an idea about where the unemployment starts and what kind of forms and varieties will be taken during the economic development. In most of the backward economies whose employment capacity and capacity are insufficient, and the population is growing rapidly, unemployment is a structural character. Seasonal unemployment, though, at certain times, gives a visible density. On the one hand, the apparatusing of the back economy leads to technological unemployment, while on the other hand it renders circular unemployment in the following stages. In the meantime, drowning and obstruction in various ways may have undergone economic development from time to time. After the development continues and the production equipment is in a mature phase, it is necessary to take into account the continuous unemployment as well as the continuous stagnation. For this reason, when we look at the flow of history collectively, it is seen that the economy, which started with a basic and widespread unemployment in the first stage against the lack of population, faces another form of based and widespread unemployment in the last stage between the various shapes and varieties (Ülgener, 1976, p. 118).

With the closure of the ring, a few centuries of progress and development can be considered to have reached the end of its life. There are other issues that should not be kept out of sight in the examination of the above explanations.

First of all, it should be pointed out that the types of unemployment that are mentioned in this article are rarely seen on their own. One is often mixed with others. This situation affects the duration and severity of unemployment. Technological unemployment in any field, combined with seasonal unemployment, may also be exacerbated by the tightness of employment elasticity at other sites. While each one is actually relatively malevolent, there is a problem in which all of them come together and spread. Unemployment in the developing countires (backlanders) would be structurally settled if they were not solved urgently. 


\section{S. Aşç1 - S. Öz 11/4 (2019) 3221-3244}

Another point that will attract our attention in the grouping of unemployment is the free form of the economically advanced and mature countries and the evolving form and varieties belonging to the countries which are underdeveloped or in the first stages of development.

With its wide and common lines, some of these shapes are the unemployment which is the result of the inadequacy of total demand in the countries that have set up the production device. The other part is the unemployment forms that stem from the failure of the overpopulation of poor and undeveloped (backward) countries to the frustrated machine.

As a matter of fact, the difference in the interpretation of unemployment by the economists since the last century is also due to this departure. While Marx explained unemployment with a widening of a substitute worker army, ie a surplus of population, which was deprived of his ownership in the capitalist order, Keynes stated that despite the maturity and surplus age, the total capital of the capitalist economy would be the problem of the capitalist economy.

Unemployment, which is clearly seen by Malthus, is a form of unemployment that is common in eastern countries with overpopulation.

\section{DYNAMIC FACTORS THAT EFFECTS UNEMPLOYMENT AND EMPLOYMENT POLICIES IN TURKEY}

Turkey, as a deveoloping country, has also employment problems during its economic view. In this part of the study, it is mentioned and analyzed both dynamic factors and with the fact that of these reality, Turkey's employment policies have been literated.

\subsection{The Dynamic Factors of Turkey's Unemployment}

Employment has some indexes over population and the population is classified as under and above 15 ages. Above 15 ages, the population is called active population. Within the active population, some people stays in the labour force and the rest is not. Within that labour force some of the people are not employed, which allows to calculate the unemployment of Turkey. Table 1 shows the non-institutional population by labour force satus which is driven by TURKSTAT within the years 2005-2019. Every row is calculated as the average value of the 12 months. Fort he year 2019, just Jabuary and Februray has been included.

Table 1 indicates that, unemployment rate has been fluctuated in between 8.4 and $14.7 \%$. For Turkey, the most critisized matter is the fact that Labourforce participation rate of the whole active population. The rate is almost the half of the whole active population.

One of the important thing is that the unemployment should be analyized with in three sector; namely Agriculture, Industry and Service sectors. To be able to follow the urban unemployment, the values should be separeted into agricultural and non-agricultural area. Hence, Tablo 1 shows that non-agricultural unemployment rate is always and almost 2 point greater than the unemployment rate. This has a meaning that agriculture sector has lower unemployment rate than the whole. This implies that assumptions are accepted as employed in the agriculture sector. 
Table 1: General Status of Unemployment and Labour Force in Turkey.

\begin{tabular}{|c|c|c|c|c|c|c|c|c|c|}
\hline \multicolumn{10}{|c|}{ Non-Institutional Population by Labour Force Status. (15 and + age; thousand person) } \\
\hline$\underset{\circlearrowright}{\mathscr{\Xi}}$ & 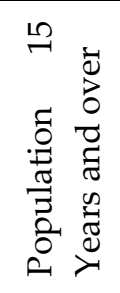 & 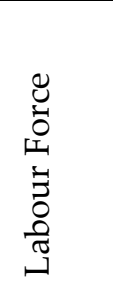 & 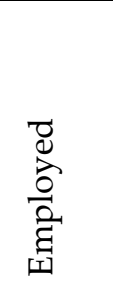 & 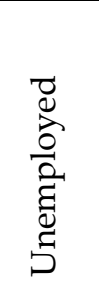 & 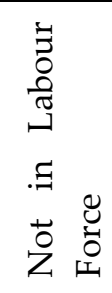 & 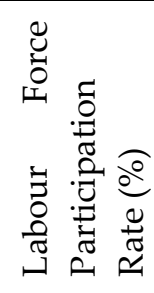 & 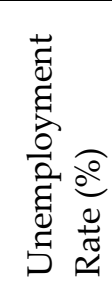 & 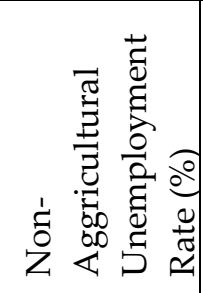 & 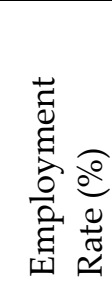 \\
\hline 2005 & 48356 & 21691 & 19633 & 2058 & 26665 & 44.9 & 9.5 & 12.0 & 40.6 \\
\hline 2006 & 49275 & 21913 & 19933 & 1980 & 27362 & 44.5 & 9.0 & 11.1 & 40.5 \\
\hline 2007 & 50177 & 22253 & 20209 & 2044 & 27925 & 44.3 & 9.2 & 11.2 & 40.3 \\
\hline 2008 & 50982 & 22899 & 20604 & 2295 & 28083 & 44.9 & 10.0 & 12.3 & 40.4 \\
\hline 2009 & 51833 & 23710 & 20615 & 3095 & 28124 & 45.7 & 13.1 & 16.0 & 39.8 \\
\hline 2010 & 52904 & 24594 & 21858 & 2737 & 28310 & 46.5 & 11.1 & 13.7 & 41.3 \\
\hline 2011 & 53985 & 25594 & 23266 & 2328 & 28391 & 47.4 & 9.1 & 11.3 & 43.1 \\
\hline 2012 & 54961 & 26141 & 23937 & 2204 & 28820 & 47.6 & 8.4 & 10.3 & 43.6 \\
\hline 2013 & 55982 & 27046 & 24601 & 2445 & 28936 & 48.3 & 9.0 & 10.9 & 43.9 \\
\hline 2014 & 56986 & 28786 & 25933 & 2853 & 28200 & 50.5 & 9.9 & 12.0 & 45.5 \\
\hline 2015 & 56986 & 29678 & 26621 & 3057 & 28176 & 51.3 & 10.3 & 12.4 & 46.0 \\
\hline 2016 & 58720 & 30535 & 27205 & 3330 & 28185 & 52.0 & 10.9 & 13.0 & 46.3 \\
\hline 2017 & 59894 & 31643 & 28189 & 3454 & 28251 & 52.8 & 10.9 & 13.0 & 47.1 \\
\hline 2018 & 60654 & 32274 & 28738 & 3537 & 28380 & 53.2 & 11.0 & 12.9 & 47.4 \\
\hline 2019 & 61101 & 32084 & 27355 & 4730 & 29017 & 52.5 & 14.7 & 16.9 & 44.8 \\
\hline
\end{tabular}

Soruce: TURKSTAT, Labour Force Statistics, 2019.

The employed people, is generally analyized in different segmentation. One of them is the agriculteral and nonagriculturel sector. Hence, it is stated also, gender, regional, youth and some other segmentations. Table 2 shows the sectorel labour force indicators as seasonally adjusted.

The Table 2, obviously indicates that service sector has in increase as having employee as labour market. The second and important point is the increase and high series of Youth Unemployment.

In Table 3, the reasons of being not in labour force has been categorized for Turkey. TURKSTAT gives the last 5 years fort he reasons. According to the definition of being in labour force for active population, the people sould not seeking a suitable job with in the reference period. And as with the same assumptions, even they find a job they could not available to start a job. And hence, the table shows that the definition has conflict for some of the people on these two assumptions. Meanwhile the biggest pie of being not in the labour force is the women, who are housewife. 
Table 2: Seasonally Adjusted Main Labour Force Indicators (15 and over age, Thousand Person)

\begin{tabular}{|c|c|c|c|c|c|c|c|c|c|c|c|c|c|}
\hline \multirow[b]{4}{*}{ Year } & \multicolumn{13}{|c|}{ Labour Force Seasonal Adjusted } \\
\hline & \multirow{3}{*}{$\begin{array}{l}8 \\
0 \\
0 \\
1 \\
\vdots \\
0 \\
0 \\
0 \\
\Xi\end{array}$} & \multirow{3}{*}{ 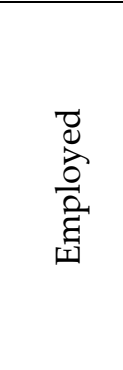 } & \multirow[b]{3}{*}{ 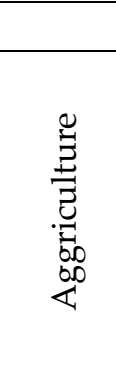 } & \multicolumn{4}{|c|}{ Economic Activities } & \multirow[b]{3}{*}{ 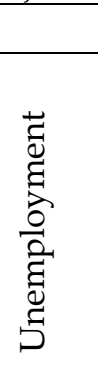 } & \multicolumn{5}{|c|}{ Rate of $(\%)$} \\
\hline & & & & \multicolumn{4}{|c|}{ Non Aggriculture } & & \multirow{2}{*}{ 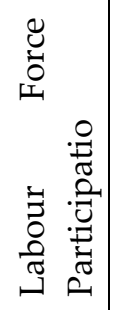 } & \multirow[b]{2}{*}{ 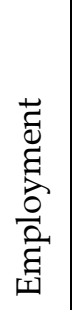 } & \multirow[b]{2}{*}{ 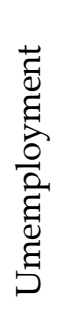 } & \multirow[b]{2}{*}{ 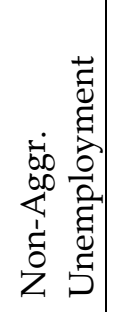 } & \multirow[b]{2}{*}{ 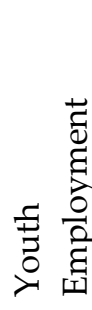 } \\
\hline & & & & 胥 & 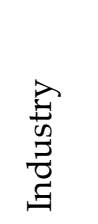 & 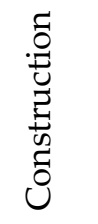 & 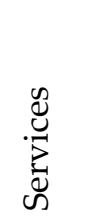 & & & & & & \\
\hline 2005 & 21667 & 19608 & 5028 & 14580 & 4231 & 1090 & 9259 & 2059 & 45 & 41 & 9 & 12 & 18 \\
\hline 2006 & 21928 & 19947 & 4663 & 15284 & 4355 & 1183 & 9747 & 1981 & 45 & 40 & 9 & 11 & 17 \\
\hline 2007 & 22279 & 20239 & 4570 & 15669 & 4411 & 1234 & 10025 & 2040 & 44 & 40 & 9 & 11 & 17 \\
\hline 2008 & 22885 & 20591 & 4605 & 15986 & 4538 & 1241 & 10207 & 2294 & 45 & 40 & 10 & 12 & 18 \\
\hline 2009 & 23740 & 20647 & 4758 & 15889 & 4188 & 1300 & 10401 & 3092 & 46 & 40 & 13 & 16 & 23 \\
\hline 2010 & 24618 & 21883 & 5110 & 16773 & 4599 & 1441 & 10733 & 2735 & 47 & 41 & 11 & 14 & 20 \\
\hline 2011 & 25559 & 23227 & 5391 & 17836 & 4858 & 1665 & 11313 & 2332 & 47 & 43 & 9 & 11 & 17 \\
\hline 2012 & 26156 & 23955 & 5294 & 18662 & 4913 & 1716 & 12032 & 2200 & 48 & 44 & 8 & 10 & 16 \\
\hline 2013 & 27099 & 24650 & 5203 & 19447 & 5114 & 1793 & 12540 & 2449 & 48 & 44 & 9 & 11 & 17 \\
\hline 2014 & 28776 & 25917 & 5455 & 20462 & 5310 & 1901 & 13251 & 2860 & 51 & 45 & 10 & 12 & 18 \\
\hline 2015 & 29690 & 26636 & 5465 & 21171 & 5338 & 1920 & 13913 & 3054 & 51 & 46 & 10 & 12 & 19 \\
\hline 2016 & 30546 & 27216 & 5306 & 21911 & 5297 & 1993 & 14620 & 3330 & 52 & 46 & 11 & 13 & 20 \\
\hline 2017 & 31642 & 28191 & 5457 & 22734 & 5391 & 2096 & 15247 & 3451 & 53 & 47 & 11 & 13 & 21 \\
\hline 2018 & 32273 & 28725 & 5303 & 23422 & 5652 & 1993 & 15277 & 3548 & 53 & 47 & 11 & 13 & 20 \\
\hline 2019 & 32412 & 28051 & 5145 & 22907 & 5390 & 1686 & 15831 & 4361 & 53 & 46 & 13 & 16 & 25 \\
\hline The $\mathrm{u}$ & mlon & nt vari & was & & the & of & & & & & & & \\
\hline
\end{tabular}

Source: TURKSTAT, Labour Force Statistics, 2019.

Table 3: Reasons of not Being in Labour Force From 2014-2019 (15 and over age, Thousand Person)

\begin{tabular}{|c|c|c|c|c|c|c|c|c|c|}
\hline \multirow{3}{*}{ Year } & \multirow{3}{*}{ Total } & \multicolumn{8}{|c|}{ Reasons } \\
\hline & & \multirow{2}{*}{\multicolumn{2}{|c|}{$\begin{array}{c}\text { Not seeking a job, } \\
\text { but available to } \\
\text { start }\end{array}$}} & \multirow{2}{*}{$\begin{array}{l}\text { Working } \\
\text { Seasonally }\end{array}$} & \multirow{2}{*}{$\begin{array}{c}\text { House- } \\
\text { wife }\end{array}$} & \multirow{2}{*}{$\begin{array}{c}\text { Eductaion } \\
\text { and } \\
\text { Training }\end{array}$} & \multirow[t]{2}{*}{ Retired } & \multirow{2}{*}{$\begin{array}{l}\text { Disabled, } \\
\text { Old, Ill, } \\
\text { etc. }\end{array}$} & \multirow[t]{2}{*}{ Other } \\
\hline & & & & & & & & & \\
\hline 2014 Annual & 28200 & 615 & 1869 & 94 & 11589 & 4470 & 3827 & 3922 & 1814 \\
\hline 2015 Annual & 28176 & 676 & 1725 & 94 & 11498 & 4486 & 4082 & 3878 & 1736 \\
\hline 2016 Annual & 28185 & 658 & 1762 & 89 & 11098 & 4541 & 4160 & 4036 & 1843 \\
\hline 2017 Annual & 28251 & 637 & 1627 & 85 & 11133 & 4467 & 4366 & 4009 & 1926 \\
\hline
\end{tabular}


M. S. Aşçı - S. Öz 11/4 (2019) 3221-3244

\begin{tabular}{|c|c|c|c|c|c|c|c|c|c|}
\hline 2018 Annual & 28380 & 546 & 1624 & 155 & 11061 & 4472 & 4536 & 4040 & 1944 \\
\hline $\begin{array}{c}2019- \\
\text { February }\end{array}$ & 29017 & 621 & 1754 & 142 & 11127 & 4591 & 4834 & 3994 & 1953 \\
\hline $\begin{array}{r}* \\
\text { * These were the persons seeking a job for reasons such as being seasonal workers busy with household } \\
\text { chores, students, property income earner, retired or disableb but available to start a job. }\end{array}$ \\
\hline
\end{tabular}

Source: TURKSTAT, Labour Force Statistics., Temmuz 2019.

\subsubsection{Corruption of the Intangible Values}

The subject that economists are most interested in is the behavior of individuals in groups. Although these behaviors appear to be the sum of the individual movements in total, the result is different from the tendencies of personal behaviors, since one would actually be under the influence of the other.

The individual consumption functions are never independent in their behavior and reactions, but they are in contact with each other. One can always influence the other. This commitment and mutual influence were clearly dealt with by J. Duesenberry in his work, Sawing and the Theory of Consumer Behavior, which led to the explanation of another trend of importance. This trend called demonstation effect is the essence of this trend:

Individuals and families in certain levels of income show a great impatience to reach the consumption standard of the prosperous families, whose revenues have grown a little when they have been in contact.

This means that consumption expenditures, in the case of a small increase in income, jump to the top of the standards of the consumption standard represented by the income group they belong to (Ülgener, 1976, p. 177).

Parallel to the stratification of social life, the standards of consumption listed below are as follows; imitation, wisdom, showing ways to climb from one to the other created a social values and behavior. The imitation and the wisdom can operate from one group to the other within the same community, as well as between separate and distant societies. The role of novels, magazines and films in the international relations of our age in this issue is so clear that it does not require a long explanation.

What is said above is not, in fact, unknown. The divisions and separations of the type of caste are one of the known and known cases of contact, entry and exit between the social layers. As in the past, the shortest way to claim a higher status today is to match the consumption standard to the requirements and dimensions of the status at the earliest opportunity. This is by far the most used and wide range of used goods to see the inferior, and it is more likely to rise to expensive consumer goods.

The event was presented by Thorstein Veblen, an American economist and sociologist, in the theoretical aspect as well as known to everyone as a historical fact (Veblen, 1899). Demonstrative Consumption Since Veblen, demonstrative consumption is one of the terms that is so common in economic terms. The issue is that the national economy is not only specific to consumption behavior and consumer goods. At the same time, it is known that even the means of production attained at the expense of limited credit and foreign exchange resources of the country are often used to show off outside the productive objectives.

The factors that prevent individuals from spending their income in the countries of the advanced industry, often in the country we call underdeveloped, in turn, emerge as incentives that reduce savings and accelerate spending.

Formation of reserves for predetermined or undetermined needs, obsolescence and erosion in equipment, or amount of depreciation to cover the possibility of crossing the day did not become a settled tradition as in advanced economies.

In fact, it is an expression of the impatient, capricious businessman mentality found in most of the less developed countries, that the effort to direct his capital to jobs that provide immediate and abundant profits and to transfer them from one place to another makes it difficult for savings to reach the expected level even in high incomes. 


\section{S. Aşçı - S. Öz 11/4 (2019) 3221-3244}

Formal goods, which will not be underestimated even in advanced countries, will attract more attention in less developed countries and in our country in the meantime. We can come across with every occasion the examples of this kind of consumption at the top-level income levels: It is a fact that the real estate and real estate goods gain value and meaning as a tool of demonstration in high income levels. In the middle income classes, the situation is not much different. It is one of those cases that are heard and seen every day when goods that are not a humble income fee (especially ornamental and jewellary goods) are sold and stopped on the basis of the intention of showing up and with the intention to rise up.

Significance of the enthusiasm to the economic and technical development is the most common signs in the agricultural sector: it is often seen that the number of tractors is now regarded as a sign of supremacy, and that the tractor and its peer is used as a passenger for wedding and games in the surrounding towns and villages.

From all these explanations, it is understood that the fictional consumption is not foreign to our history and society.

The issue concerns us here as a factor that rebellions during economic development and development, and which carries the desire to delay development.

All these behaviors are essentially the main motif of waste. This, in turn, leads to contraction and decline in investment volume based on lack of resources, and to individual job searches seen as a result of income insufficiency, efforts to make several jobs and to work again after retirement.

As a result of all these, it leads to employment contraction.

\subsubsection{Inadequacy of Education System}

High educators in developing economies, or unemployment, which is generally seen among the educators, is an extremely important problem in terms of its political and social consequences. This is undoubtedly seen as a result of a bad investment and manpower policy (Ekin, 1971, p. 118).

Thus, in our country, higher education has a capacity that exceeds the plan targets and the boundaries required by balanced development, and another problem is the low teacher / student ratio.

In Turkey, there are highly unstable rates especially in faculties such as Law and Literature (Kurtkan, p. 579). This has a negative effect on the employment problems limiting balanced development opportunities.

In fact, in addition to the issue of brain export in developing countries, there is no need for skilled work force for the maintenance or acceleration of economic development on the one hand, while on the other hand many elements are trained in the qualifications and profession that do not need their own qualifications in economic development; While the need for skilled labor within the structure is continuing, the unemployment of university graduates, who can be called as intellectual unemployment from time to time, is also observed. Since many of the undertakings are owned by the family and managed by the family members, the opportunity for employers and technicians who are vocationally trained to become employed is getting narrower.

As a result of the fact that the population growth rate is high, labor supply will increase and if this increase is not possible to be used in the existing and created technical business areas, open and covert unemployment can expand.

Thus, university graduates or, in many cases, high school graduates attend the unemployed group rather than accepting a job that does not fit the profession or finding a job in the backward, rural areas of the country. In fact, a significant portion of those who are educated as being important in terms of open unemployment is an important factor in the expansion of underemployment by forced to accept a job that does not meet the qualifications and education levels.

In this way, the widespread waste of human capital stems from the insufficiency of the investment policy for the development of human resources, as well as the social and political stability of the country. 


\section{S. Aşçı - S. Öz 11/4 (2019) 3221-3244}

Under these circumstances, those who are unemployed or not employed satisfactorily pass to professions where standards are less stringent. This process is expanding the volume of enlightened intellectuals (Schumpeter, 1942, p. 153).

The persons and / or institutions planning the human power needs for the future of the economy will lead to skilled manpower redundancy or manpower insufficiency if they make false projections.

On the other hand, it may be the source of the unemployment in some non-conformities between the qualifications demanded by the post-training employment and the qualifications given by the training.

In this context, it should be mentioned that the doctoral studies conducted in the undergraduate and especially post-graduate education abroad, especially in the fields of social science, are not related to the realities of our country (Kurtkan, p. 588). As seen, the lack of education system; i) Qualification of the personnel that the labor market does not require, ii) Unemployment at the level required by the labor market leads to unemployment through a dual interaction.

It is also stated that, in Turkey, during 1989-2008, the education level has an effect and interrelated with unemployement, the matter has a heterogeneity in labor markets. It has been tested and made clear by Lagrange Multiplier. It is clear that unemployment has changed by the attainment of the education even it is came by hysteresis (Aslan and Kula, 2014, p. 39).

On the other hand, it is a problem due to both the capacity and the fact that the vocational high schools and higher education schools are not established due to need (Kutal, 1999, p. 67). Not just high school but also universities and their quotas need to be parallel to the national strategies.

\subsubsection{Incorrect Rules (Bureaucracy)}

General characteristics of bureaucracies in less developed countries;

The inadequacy of the development efforts (qualitatively) to have the workforce with the skills they need. General attitudes and behaviors that are not directed towards development and innovation (ie bureaucracy as a means of personal, social and material satisfaction): At the simplest level, the motto "go today and come tomorrow" reflects this attitude. In bureaucratic institutions, a bureaucratic pathology is already found, such as making the tool superior. A strict understanding of law makes this pathology more serious in bureaucratic system activities, while bringing bureaucracy into a completely conservative position in inter-system relations. Under the legislation, the bureaucracy is the advocate of why any function cannot be fulfilled, rather than being a practitioner in a certain legal order (Heper, 1973, p. 117-122).

In order to save the unemployed especially had been employed and lost their jobs, insurance legislations are in use after 2007. According to the Turkish Employment Agency (abbreviated as ISKUR) during 2017, almost 1.3 million people appointed to the unemployment insurance. The same source illustrate that, almost one third of the whole applicants are blue-collared (skilled and non-skilled) workers (Turkish Employment Agency, 2019)

In this case, we can describe schematically the applications and the relationship with our subject, which we can describe as improper rules.

\subsubsection{Increase in Population}

One of the reasons for unemployment is the rapid increase in population in developing countries. The main feature of almost all of these countries is the rapid population growth. In the last two quarters of the twentieth century, the population has not been recorded in the history of the world, and the population is increasing by $2 \%$.

In developed countries, while the rate of population growth is below the world average, rates in developing countries are above this average and rates tend to increase with the passing of years. It is called the population explosion in the circles that the population grows so rapidly. This explosion, however, does not create as much noise as the backward ones in the advanced countries. Although the population of the advanced countries 


\section{S. Aşçı - S. Öz 11/4 (2019) 3221-3244}

increased by about $1 \%$ per annum, this rate increased to $3 \%$ in the backward. Turkey is also among the countries included in this second category (Ekin, 1971, p. 214-215).

Turkey was a very rapid population growth, the child age group in the total population occupied an important place, so participating in the annual labor force of young people that have a large volume and workforce readiness status as a large proportion of the employed in agriculture, in labor It is a known fact that addicts constitute a bounded rate, have a dynamic supply of labor and a country with all the characteristics of developing countries. According to TUIK, Turkey still has $1.4 \%$ increase per year at 2019 (TUIK).

It is clear that rapid population growth will have negative effects on labor supply. This is particularly important for employment. Indeed, as the population growth rate is high, labor supply will also increase, and open and clandestine unemployment may expand if it is not possible to use this increase in the existing and created business areas (Cillov, 1971, p. 558-562).

Turkey was a very rapid population growth, the child age group in the total population occupied an important place, so participating in the annual labor force young people to the presence of a large volume and labor force already state as a large proportion of the employed in agriculture, in labor It is a known fact that addicts constitute a bounded rate, have a dynamic supply of labor and a country with all the characteristics of developing countries.

The labor demand in response to the dynamic development of labor supply; and a speed realization volume of Turkey will bring remedies to the issue of employment, it is the most important factor determining the structure of employment in Turkey. In other words, the chronic imbalance between labor supply and labor demand shapes the structure of employment and limits its volume. The supply of labor in Turkey is increasing rapidly due to population growth, economic development and settlement of the issue in terms of population, employment problems and gain a special importance in settling the employment problems of population growth factor that plays a strategic role (Ekin, 1971, p. 380).

\subsubsection{Protectionism}

While trade is the source of significant gains, mostly the countries, free trade flows, customs, quotas or other barriers, protection as defined by the limitations imposed on imported goods and services are defended by workers and firms in some industries on the grounds that they protect themselves from external competition. However, such limitations often limit the amount of goods on the one hand, and increase the prices of these goods, but often constitute a burden on the whole of society. There is also a view that national labor in favor of protectionism, protecting domestic labor, lowering the domestic unemployment rate, and protecting the important industries in the defense of the country, where a newly established industry needs to be protected until reaching the dimensions and effectiveness that can withstand international competition (the baby industry argument) (Eugene and Salvatore, 1983, p. 338-348).

Inflation leads to unemployment as a result of the weakening of small and medium-sized undertakings, liquidation and not establishing new ones due to the high cost of financing caused by capital erosion and rising interest rates.

However, it is stated that protectionism leads to monopoly. It is said to cause loss of employment opportunities associated with the inability of new entrepreneurs to enter a business area. Expensive and of poor quality production, with the newer technology products caused by the inability to work with backward technology employment in durgunlaştırıc result of competition stated that the effects of the literature emphasizes the importance of the issue for Turkey.

\subsubsection{Inflation}

Inflation, which is defined as continuous and significant increase movements at general price level, decreases industrial investments, difficulties in importing spare parts and raw materials due to external payment difficulties, refrains from coming to the country where inflation is dominated due to the impossibilities of 


\section{S. Aşçı - S. Öz 11/4 (2019) 3221-3244}

foreign capital transfer and finally export difficulties of the goods produced for the foreign markets. non-export may require production branches that produce such goods to slow down or even stop operations. For these reasons, employment in the country falls (Türk, 1979, p. 80).

Moreover, inflation is the source of unemployment as a result of the weakening of small medium-sized enterprises (SME's), liquidation and not establishing new ones due to the high cost of financing caused by capital erosion and rising interest rates. Not sufficiently benefiting from science As a result of not taking advantage of science enough problems and interactions with unemployment can be listed as follows:

a) Location, field of activity, technology wrong institutions: Companies and liquidations in power (Unemployment)

b) Non-monitoring or poor copying: Expensive and poor quality production (failure to compete with the products of modern technologies) Disposal (Unemployment)

c) Not using the basic principles of working life

- Workers / employers who do not have a rational basis

- More staff, low production, restless employee

- The use of incentive wage systems

- Project management techniques are not used, investment projects are not completed on time, employment opportunity loss.

\subsubsection{Urbanization}

Urbanization in Turkey, between economic and social development and industrialization, as seen in all countries, developing a strong correlation can be identified.

In industrialized countries, the industry created by the cities and the labor it freed in the countryside created a certain balance, while in the non-industrial countries, the cities are having difficulty in finding employment for the population that is rapidly pushed from the countryside. Thus, an imbalance arises between the rate of demographic urbanization and the rate of development of city functions (Ekin, 1971, p. 360-361).

It is known that the pushing factors have a greater weight in the urbanization which has emerged with the loss of the attraction of the village and the increase of the attractiveness of the city.

In fact, in the near future, more than half of Turkey's population is now made up of people sitting in understanding the future of the city. However, the job opportunities that will increase due to industrialization will increase the importance of the city's traction as well as a balanced urbanization in terms of employment. Otherwise, it will be a rapid urbanization as a result of the village's development, but this urbanization will not be a development urbanization, but a quality of poverty urbanization. In industrialized countries, the industry created by the cities and the labor it freed in the countryside created a certain balance, while in the nonindustrial countries, the cities are having difficulty in finding employment for the population that is rapidly pushed from the countryside. Thus, an imbalance arises between the rate of demographic urbanization and the rate of development of city functions.

If Turkey wants to bring more drastic remedies in the near future as the global employment problems of rapid industrialization and economic development model, all sectors must stand strongly on policies to increase productive employment opportunities.

One more important point is the change of labour and employmnt structure of Turkey. At Table 4, there is a certain decrease of unpaid family workers during five years. This somehow illustrated with urbanization in increase. Urbanization and entrepreneurship are the main reasons of the issued decrease in unpaid family workers.

Table 4: Employment Structure By Years

\begin{tabular}{c|c|c} 
Year & Thousand Person & Percentage, \%
\end{tabular}




\begin{tabular}{|c|c|c|c|c|c|c|c|c|c|}
\hline & $\stackrel{\widetilde{\pi}}{0}$ & 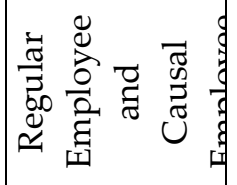 & $\frac{\overrightarrow{0}}{\stackrel{0}{0}}$ & 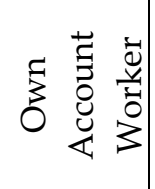 & 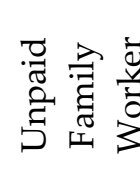 & 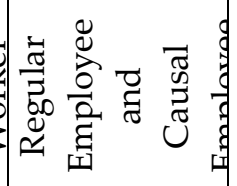 & $\frac{\grave{D}}{\grave{0}_{0}^{\circ}}$ & 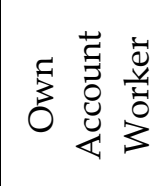 & 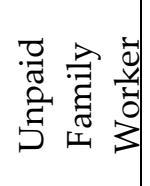 \\
\hline 2014 Annual & 25933 & 17125 & 1173 & 4479 & 3155 & 66.0 & 4.5 & 17.3 & 12.2 \\
\hline 2015 Annual & 26621 & 17827 & 1175 & 4468 & 3150 & 67.0 & 4.4 & 16.8 & 11.8 \\
\hline 2016 Annual & 27205 & 18377 & 1239 & 4536 & 3053 & 67.6 & 4.6 & 16.7 & 11.2 \\
\hline 2017 Annual & 28189 & 18960 & 1279 & 4815 & 3134 & 67.3 & 4.5 & 17.1 & 11.1 \\
\hline 2018 Annual & 28738 & 19536 & 1282 & 4909 & 3012 & 68.0 & 4.5 & 17.1 & 10.5 \\
\hline 2019-February & 27355 & 18747 & 1241 & 4749 & 2617 & 68.5 & 4.5 & 17.4 & 9.6 \\
\hline
\end{tabular}

Source: TURKSTAT, Labour Force Statistics, Temmuz 2019.

With the economic development of urbanization in Turkey, industrialization and emergence as independent from the increase of job opportunities in the city more urbanization called by some sociologist or mock urbanization leads to a demographic urbanization (Ekin, p. 362).

It is clear that such an urbanization would mean an increase in the number of people living in slums and working with low income in the service sector because of the lack of employment opportunities for the economic and social services provided in cities. In the surveys conducted in the slums among the migrants who live in the city, those who live in the slums desire to have a permanent job opportunity as the most important request. Such a demand, without doubt, implies unstable employment and income insecurity in urban life.

There are also many other effects on unemployment for any country. For instance, sustainability, social welfare, entreprenuership, energy density, energy consumption etc. But the macro changes would be occured as listed above (Öz and Teker, 2019, p. 36, Beşel, 2017, p. 22, Alagöz and Topall, 2014, p. 153).

\subsection{Turkey's Employment Policies}

Employment Policies (some academic sources indicate as "Labour market policies") implemented in Turkey, are examined divided into two basic groups such as passive and active employment policies. (Murat, 2007, s. 205209)

\subsubsection{Passive Employment Policies in Turkey}

The basic passive labor market policies implemented in Turkey means is unemployment insurance. The unemployment benefit, another passive labor market, is not applied in our country. However, as in some countries, practices such as wage guarantee fund, short work allowance, severance pay, notice pay and job loss compensation are considered among passive employment policy instruments. (Mahiroğulları \& Korkmaz, 2013, s. 86) In this context, especially unemployment insurance in Turkey; It can be said that there are six passive Employment Policy instruments consisting of wage guarantee fund, short working allowance, severance pay, notice pay and job loss compensation. (Işı̆̆ıçok, 2018, s. 268)

\section{- Unemployment Insurance}

Unemployment insurance is a social security program developed for those who have the desire and ability to work and who have lost their jobs against their will, to temporarily, to cover part of their previous income, to prevent them and their family from socio-economic difficulties. (Erol, Özdemir, \& Yurdakul, 2010, s. 18-19). Unemployment insurance in Turkey, was founded 25 August 1999 with the Law No. 4447. (Erol, Özdemir, \& Yurdakul, 2010, s. 16-17) 


\section{S. Aşçı - S. Öz 11/4 (2019) 3221-3244}

Unemployment insurance is designed as a group insurance for workers who have lost their jobs against their will. (Biçerli, 2004, s. 279) The premiums are based on tripartite financing and are calculated over a certain percentage of the gross premium. As a matter of fact, the sum of the premiums consists of $1 \%$ of the monthly premium income of the insured worker, 2\% of employer and 1\% of state contributions. (Özgüler \& Biçerli, 2012, s. 158)

The purpose of unemployment insurance according to Article 46 of Law No. 4447 is stated as: "to regulate the rules and principles of unemployment insurance and to ensure that the insured receive the payment and services provided in this Law in case of unemployment". In order to benefit from unemployment insurance, that is to be entitled to unemployment benefit, certain conditions must be fulfilled. Some of these:

- To be included in the scope of the Law,

- The termination of the working relationship in accordance with the criteria specified by the law,

- Worked as an insured person for 600 days in the last three years and paid unemployment insurance premiums,

- Worked continuously by paying premiums within the last 120 days before leaving the job.

According to Article 48 of Law No. 4447, the unemployed who are eligible to receive unemployment insurance payments to be made by Turkey Business Council and assistance are provided:

- Unemployment benefit,

- sickness and maternity insurance premiums,

- Finding new jobs and

- Professional development, acquisition and training.

The daily unemployment allowance is calculated as $40 \%$ of the daily average gross earnings calculated by taking into consideration the insured's earnings for the last 4 months. However, the amount of unemployment benefit calculated in this way cannot exceed $80 \%$ of the gross wage of the minimum wage. (Erol, Özdemir, \& Yurdakul, 2010, s. 19-21)

Unemployment benefit periods; Those who have worked continuously by paying premiums for the last 120 days before the termination of the employment contract, within the last 3 years;

- 180 days for insured unemployed people who have worked for 600 days as insured and paid unemployment insurance premium,

- 240 days for insured unemployed persons who have been insured for 900 days and paid unemployment insurance premiums,

- It is applied as 300 days for the insured unemployed who have worked for 1080 days and paid unemployment insurance premium. (Işı̆̆ıçok, 2018, s. 272)

The establishment of unemployment insurance in Turkey, albeit an extremely important development; it is too late compared to developed western countries. As a matter of fact, considering that unemployment insurance has been established and started to be implemented in most of the developed countries in the first quarter of the 20th century; it is clear that our country is quite late in this field. However, we can say that the implementation of unemployment insurance in our country is a positive start even if it is not sufficient in terms of both the amount of allowance and the amount of time provided. In many developed and applied in many other countries have adopted the principle of social state is a passive Employment Policy tool that unemployment benefits do not apply in Turkey. On the other hand, other passive labor policies which consist of wage guarantee fund, short working allowance, severance pay, notice pay and job loss compensation are applied in our country. (Işı̆̆ıçok, 2018, s. 274) 


\section{- Wage Guarantee Fund}

Wage Guarantee Fund; is an Employment Policy tool to protect workers against the economic hardships employers face, to ensure that they will receive wages at least for a certain period of time. (Korkmaz \& Mahiroğulları, 2007, s. 116) The Wage Guarantee Fund application entered into the Turkish working life with the Labor Law No. 4857 adopted on 22 May 2003. Financing of the Wage Guarantee Fund, whose purpose is to guarantee the three-month wage receivables arising from the labor relations in case the employer falls into the payment difficulty, is financed by the Social Security Institution and collected by the Social Security Institution over the premiums transferred to the unemployment insurance fund. (Findık, 2007, s. 16)

\section{- Short Work Allowance}

In case of short working allowance, general economic, sectoral or regional crisis and compelling reasons, the weekly working hours in the workplace are temporarily reduced or the activity in the workplace is stopped temporarily or partially; Not to exceed 3 months to the insured, in proportion to the period in which they do not work; is an application that provides income support. (Özgüler \& Biçerli, 2012, s. 158)

The daily short-time working allowance is $60 \%$ of the average daily gross earnings calculated by taking into consideration the insured's earnings under the premium for the last 12 months. This amount cannot exceed the gross minimum wage. (İsssizlik Sigortası Fonu, 2011, s. 3)

\section{- Part Time (Half Working Day) Allowance}

Pursuant to the additional article 5 of the Unemployment Insurance Law No. 4447, the employee is paid half of the weekly working time for half of his working time in accordance with the second paragraph of Article 4857 of Labor Law. In December 2016, TL 937,060 was paid to 1398 people. (İssizizlik Sigortası Fonu, 2016, s. 2)

\section{- Severance Pay}

In general terms, severance pay is the money paid to the employee whose employment contract is terminated according to the period he worked (Iş1klı, 2005, s. 106). The main purpose of severance pay; to prevent employers from easily dismissing workers. In addition, the provision of severance pay to the employee whose employment contract is terminated in accordance with the conditions is of utmost importance in terms of providing job security for the workers. Severance pay is an application that aims to ensure that employers cannot easily dismiss the workers they have employed, that is, to provide job security in the workplaces rather than rewarding the workers whose employment contract is terminated and dismissed. (Varçın, 2004, s. 19)

However, in some countries, since severance pay is considered as an alternative to unemployment insurance, unemployment insurance and severance pay are not applied together.

\section{- Notice Compansation Payment}

Notice compensation is the payment made for the periods corresponding to the period of notice given in the annuled termination if the employer wishes to immediately dismiss the employee without complying with the notification periods. Notice compensation is considered as an unemployment benefit that the employee can benefit from in case of termination of the employment contract without prior notice, until the employee finds a new job. (Işı̆̆ıçok, 2018, s. 282)

\section{- Job Loss Compensation}

Job loss compensation is a compensation paid to the unemployed labor force under privatization. The benefit of this application is the insured unemployed unemployed who lost their jobs due to privatization and were entitled to job loss compensation. (İŞKUR, 2019)

The purpose of compensation for loss of work is to pay a fee based on a service contract in the entities included in the scope of privatization, except for affiliates, the provision of income and social security for a period of time to those expired in accordance with labor laws and collective bargaining agreements. (IŞKUR, 2019) 


\subsubsection{Active Employment Policies in Turkey}

Active Employment Policies (Active Labor Market Policies) in Turkey has become increasingly important, especially since the 1990s, but has not yet reached a sufficient level desired. (Uşen, 2007, s. 83)

Active labor market policies are seen as separate applications in the first phase has been widely began to be implemented in Turkey since 2009 (Özgüler \& Biçerli, 2012, s. 159). In this context, it can be said that Turkey is too late compared to developed western countries in terms of the implementation of active labor market policies.

If needed to classify the active labor market policies implemented in Turkey; of course, labor training courses through vocational training will undoubtedly come first. Labor and vocational courses will be followed by incentives to increase investment and employment. In other words, active labor market policies implemented in Turkey;

- Labor force training courses (labor force training courses through vocational training programs),

- Job and vocational counseling services,

- Incentives to increase investments and employment.

\section{CONCLUSION AND DISCUSSION}

Since 1960, the efforts to identify the issues of unemployment in Turkey, still claims to be able to sufficiently clarify the issue opening is unlikely. Until 1980, such as Turkey, where certain data on unemployment is very limited, labor market, labor, economic and social structure, the organization of production, up to 2007 the lack of unemployment insurance, rural and agricultural life of certain properties arising from the outcome of the subject that is even more difficult to deal with all aspects obvious. Approaches to unemployment are not the subject of monographic research, but rather the subject of detailed research to be carried out at the micro level in planning. Otherwise, assumptions cannot go beyond speculative estimates.

In fact, at least to make Turkey a robust analysis of unemployment data known to some, to undertake some research, within the terms of employment and unemployment need to be subjected to more thorough analysis. Unless this is done, unemployment research cannot go beyond putting forward a broad framework.

Another striking point, Turkey's efforts in matters of plans determine the volume of unemployment in our country, the work is the same rigor and emphasis on policies to boost employment unformed orientation. New models, new possibilities were not introduced, only the Western countries, the acceleration of labor flow, family planning, encouragement of the construction sector, the preference of labor intensive techniques, such as the fact that the theoretical remaining and some of the classic proposals remain within the framework (Ekin, 1971, p. 399).

Another very important factor that reduces the importance of village life in the traditional sectors of the unemployment issue in Turkey and the safety benefit of the extended family system. Due to the limited employment capacity of the industrial sector, the change in the structure that emerged with urbanization tends to carry the employment problems in the agricultural sector to the modern sector and the service sectors are growing rapidly.

If Turkey wants to bring more drastic remedies in the near future as the global employment problems of rapid industrialization and economic development model, all sectors must stand strongly on policies to increase productive employment opportunities.

As indicated, there has been many reason for real unemployment. They are also acceptable for Turkey. But especially after 2008 - 2009 political issues have been changed and hence, unemployment has a positive relations with the general economic activity, indexed by GDP. According to Artur Okun, it is obvious that unemployment would be in increase, but beyond this economic negative slope, in growth, technology and the changing labor 


\section{S. Aşçı - S. Öz 11/4 (2019) 3221-3244}

market has a short and medium term negative effect on employment. This fact, says that new researches should be handled under the technological transformation.

Especially when considering the last two decades, passive employment policy is being used effectively in Turkey, but active employment policy is not. Even some activities show that there are some evidance, the statistical results show still insufficient to be able to decrease the unemployment. Since technology has a potentially increasing graph, the current policies shuld be urgently rejuvenesced. Especially the part of education should be coordinated with the coming policies.

\section{REFERENCES}

Alagöz, M., \& Topallı, N. (2014). Energy Consumption and Economic Growth In Turkey: An Empirical Analysis. Journal of Institute of Social Sciences, 32, 153.

Aren, S. (2008). İstihdam Para ve Iktisadi Politika (10 ed.). Savaş Yayınları.

Aslan, A., \& Kula, F. (2014). Unemployment Hysteresis in Turkey: Does Education Matter? Internatıonal Journal of Economics and Financial Issues, 4(1), 39.

Ay, S. (2012). Türkiye'de İşsizliğin Nedenleri: İstihdam Politikaları Üzerine Bir Değerlendirme. Yönetim ve Ekonomi, 19(2), 336.

Beşel, F. (2017). Energy Consumption Unemployment nexus in Turkey. The International Journal of Economic and Social Research, 13(2), 22.

Beveridge, W. H. (2014). Full Employment in a Free Society (Works of William H. Beveridge): A Report. Routledge, 248.

Biçerli, M. K. (2004). İsssizlikle Mücadelede Aktif İstihdam Politikaları. Eskişehir: T.C Anadolu Üniversitesi Yayınları.

Cillov, H. (1971). Nüfus Artışının İktisadi Gelişme ile Münasebeti, Türkiye'nin İktisadi Gelişme Meseleleri. Sermet Matbaasi.

Civelek, E. (2018). Humans of Machine Age: Management Strategies For Redundancy. JITAL, 91.

Ekin, N. (1971). Gelişen Ülkelerde ve Türkiye'de İşsizlik. İstanbul: Sermet Matbaası.

Ekin, N. (n.d.). Şehirleşme Sorunları, Özel İhtisas Raporu. Devlet Planlama Teşkilatı (DPT).

Erol, H., Özdemir, A., \& Yurdakul, E. (2010). Türkiye'de İşsizliğin Yolaçtığı Olumsuz Sonuçların Giderilmesinde 4447 Sayılı İssizlik Sigortası Kanununun İşlevi. Tisk Akademi Dergisi 2, 7-37.

Eugene, D. A., \& Salvatore, D. (1983). The Principles and Terms of Economy. Türkiye Ekonomi Kurumu Yayını.

Fındık, E. (2007). Avrupa Birliği ve Türkiye'de Ücret Garanti Fonu Uygulamaları Karşılaşılan Sorunlar ve Çözüm Önerileri. Ankara: Uzmanlık Tezi.

Heper, M. (1973). Modernleşme ve Bürokrasi. Sosyal Bilimler Derneği Yayınları.

Işığıçok, Ö. (2018). İstihdam ve İsssizlik. Bursa: Ekin.

Işıklı, A. (2005). İş Hukuku. Ankara: İmaj Yayınları.

İ̧̧KUR. (2019, Mayıs 10). işkur. Retrieved Mayıs 10, 2019, from Türkiye Cumhuriyeti İş ve İşçi Bulma Kurumu: http://iskur.gov.tr 


\section{S. Aşç1 - S. Öz 11/4 (2019) 3221-3244}

İşsizlik Sigortası Fonu. (2011). Aralık Sayısı. İsssizlik Sigortası Fonu, 3.

İşsizlik Sigortası Fonu. (2016). İşsizlik Sigortası Fonu. Aralık Sayısı, 2.

Korkmaz, A., \& Mahiroğulları, A. (2007). İsssizlikle Mücadelede Emek Piyasası Politikaları. Bursa: Ekin Basım Yayın Dağıtım.

Kurtkan, A. (n.d.). Türkiye'de Orta Yüksek Öğretim, Türkiye'de İktisadi Gelişme Meseleleri (Vol. 1). Sermet Matbaa.

Kutal, G. (1999). Türkiye'de İsssizlik Sorunu ve İsssizlerin Yaş Gruplarına ve Eğitim Durumuna Göre Dă̆glımı. Mercek.

Lewis, W. A. (2013). The Theory of Economic Growth. Routledge.

Mahiroğulları, A., \& Korkmaz, A. (2013). İşsizlikle Mücadelede Emek Piyasası Politikaları. Bursa: Ekin.

Murat, S. (2007). Dünden Bugüne İstanbul'un İşgücü ve İstihdam Yapısı. İstanbul: ITO.

Öz, S. (2017). 1980 Sonrası Türkiye'de Maliye Politikaları ile Gelir Dağılımı ve Sosyal Adalet İlişkileri. İstanbul: Hiperlink.

Öz, S., \& Teker, R. (2019). Renewable Energy, Growth and Employment Relations: A Case Study in Turkey. ICSEEC, (p. 36). Muğla.

Özay, M., \& Kılıç, C. (2009). Labor Economics Theory. Gazi Yayınları, 10-19.

Özgüler, V., \& Biçerli, M. (2012). İstihdam ve İşsizlik. In S. Tekeli, V. Özgüler, Ç. Özdemir, \& M. Biçerli, İstihdam ve İssizlik (pp. 157-159). Eskişehir: Anadolu Üniversitesi Yayını.

Schumpeter, A. J. (1942). Capitalism, Socialism and Democracy. London: George Allen and Unwin Ltd.

Seyyar, A. (2011). Sosyal Politika Bilimine Giriş. Sakarya: Sakarya Yayıncllık.

The Balance. (2019, June 1). Retrieved from Types of Unemployment (online): https://www.thebalance.com/typesof-unemployment-3305522

TUIK. (n.d.). Retrieved June 2, 2019, from Hanehalk1 Anketleri (online): https://www.tuik.gov.tr, l.e

Turkish Employment Agency. (2019). Retrieved June 8, 2019, from ISKUR (online): https://www.iskur.gov.tr/kurumsal-bilgi/istatistikler/, l.e. 8th

Türk, İ. (1979). Maliye Politikası. Ankara: S Yayınları.

Uşen, Ş. (2007). Avrupa Birliği Ülkeleri Ve Türkiye'de Aktif Emek Piyasası Politikaları. Çalışma ve Toplum, 2(13), 65-95.

Ülgener, S. (1976). Milli Gelir, İstihdam ve İktisadi Büyüme. İstanbul: Der Yayınevi.

Üstünel, B. (1990). Makro Ekonomi. İstanbul: Misırlı Matbaası.

Varçın, R. (2004). İstihdam ve İşgücü Piyasası Politikaları. Ankara: Siyasal Kitabevi.

Veblen, T. (1899). The Theory of the Leisure Class. Macmillian.

Zaim, S. (1977). Çalışma Ekonomisi. İstanbul: Elektronik Ofset. 